Research Article

\title{
Microstructure and Hardness of Cold Work Vanadis 6 Steel after Subzero Treatment at $-140^{\circ} \mathrm{C}$
}

\author{
Juraj Ďurica, Jana Ptačinová, Mária Hudáková, Martin Kusý, and Peter Jurči
}

Faculty of Materials Science and Technology in Trnava, Slovak University of Technology, Jána Bottu 2781/25, 91724 Trnava, Slovakia

Correspondence should be addressed to Peter Jurči; p.jurci@seznam.cz

Received 25 October 2017; Accepted 9 January 2018; Published 4 March 2018

Academic Editor: Carlos Garcia-Mateo

Copyright (C) 2018 Juraj Durica et al. This is an open access article distributed under the Creative Commons Attribution License, which permits unrestricted use, distribution, and reproduction in any medium, provided the original work is properly cited.

The microstructure, phase constitution, and hardness of $\mathrm{Cr}-\mathrm{V}$ ledeburitic tool steel Vanadis 6 subjected to subzero treatment at $-140^{\circ} \mathrm{C}$ and for different soaking times have been investigated. The light microscopy, scanning electron microscopy, and X-ray diffraction have been used for microstructural investigations. The hardness has been evaluated by the Vickers method. The obtained results assist to draw that subzero treatment reduces the retained austenite amount and increases the population density of carbides, compared to conventional heat treatment. The extent of decrease in the retained austenite amount makes around $85 \%$, and the increase in population density of small globular carbides was approximately fivefold. High compressive stresses were identified in the retained austenite, and their values follow the increase in carbide count. This makes a serious support to the theory explaining the formation of "extra" carbides as a by-product of more complete martensitic transformation. As a result of the mentioned microstructural changes, the material hardness increased from $875 \pm 16 \mathrm{HV} 10$ up to $954.6 \pm 14 \mathrm{HV} 10$ for conventionally quenched and SZT steels, respectively.

\section{Introduction}

One of the major problems in heat treatment of high-carbon steels is too high amount of retained austenite, which appears in their microstructure after room temperature quenching. For example, Jurči et al. [1] reported that the amount of retained austenite $\left(\gamma_{R}\right)$ in the ledeburitic tool steel Vanadis 6 was $20.2 \pm 1.6$ vol. \% after room temperature quenching from the austenitizing temperature of $1050^{\circ} \mathrm{C}$. Retained austenite is an undesirable microstructural feature as it is soft and metastable at low temperatures, and it is amenable to decompose when heavily loaded, for instance. Decomposition of the $\gamma_{R}$ is always connected with dimensional changes, which can have detrimental effect on the durability of tools and precise parts. Also, an embrittlement of the materials can occur at these circumstances since the stress-induced $\gamma_{R}$ transformation results in the formation of either the martensite or low bainite. Therefore, the retained austenite must be eliminated from the tools before use. One of the possible ways how the retained austenite can be removed is the application of high-temperature tempering.
However, some steel grades cannot be tempered above a temperature of around $200^{\circ} \mathrm{C}$, due to the risk of substantial hardness loss.

Subzero treatment (SZT) is an add-on step in the heat treatment of high-carbon high-alloyed steels where the materials are cooled down to temperatures well below the room temperature, held there for a predetermined duration, and reheated slowly to the room temperature. This kind of heat treatment leads to considerable alterations in the microstructure of steels, which can be summarized as follows:

(i) SZT steels contain considerably reduced $\gamma_{R}$ amount [1-9].

(ii) As a result of both the extensive plastic deformation and spatial limitations, the martensite of SZT steels is clearly refined compared to that developed by room temperature quenching, and it contains enhanced number of lattice defects $[1,5,10]$.

(iii) In many cases, SZT steels contain precipitates of transient carbides after reheating to the room temperature as a result of accelerated precipitation 
rate caused by various metallurgical effects of SZT [11-14].

(iv) SZT ledeburitic steels contain enhanced population density of small globular carbides (SGCs) $[1-4,8,9,14-19]$. The formation of these carbides is a result of more complete martensitic transformation as determined recently [14].

Mentioned microstructural alterations are reflected in higher as-SZT hardness $[1-3,11,14,15]$, better dimensional stability of components and tools $[20,21]$, and "extra" wear performance $[2,3,9,16,22]$. The toughness and fracture toughness are, however, worsened [23], except the cases where the steels are high-temperature tempered [24, 25].

Despite the basic metallurgical principles being responsible for alterations in the microstructure, mechanical properties and tribological performance are rather understood [14], the choice of "optimal" temperature of the SZT is still under debate.

In the middle of the 20th century, it was generally accepted that temperatures of approx. $-79^{\circ} \mathrm{C}\left(-120^{\circ} \mathrm{F}\right)$ are sufficient to transform high portion of retained austenite into the martensite and thereby make beneficial effects like additional wear resistance, increased fatigue strength, and better aging stability of steels. Lower temperatures were not used for the SZT as the experiences of heat treaters indicated that there is a great risk of failure of tools, due to thermal shocks resulting from the immersion of tools into liquid nitrogen, for instance.

Only much later, a temperature of $-196^{\circ} \mathrm{C}$ was suggested for treatment. Practical applications of tools have early shown that the treatment at the boiling temperature of liquid nitrogen further increases the wear resistance and hardness. Based on these facts, subzero treatment in liquid nitrogen became the standard processing route, and other temperatures did not have practical use in SZT. Also, the understanding of processes, which take place at cryotemperatures, has been realized by treatment of specimens at the temperature of $-196^{\circ} \mathrm{C}$.

Only few studies suggested other temperatures, for instance $-140^{\circ} \mathrm{C}[11,26]$ or, on the contrary, a temperature of liquid helium [11, 27] for the treatment of Cr ledeburitic tool steels. The obtained experimental results indicate that some processes, which are responsible for the abovementioned ameliorations in properties, may proceed faster at $-140^{\circ} \mathrm{C}$ than at $-196^{\circ} \mathrm{C}$; thus, this schedule might bring some benefits into the SZT. Alternatively, the use of the temperature of boiling helium $\left(-269^{\circ} \mathrm{C}, 4.2 \mathrm{~K}\right)$ can provide an "extra" driving force for the martensitic transformation and thereby for the formation of SGCs also. However, it is inevitable that treatment times would be very long as there is little atomic movement at such a low temperature [11].

The main goal of the current experimental works is then to make a comprehensive study on what happens in ledeburitic steels when they are subjected to the SZT at $-140^{\circ} \mathrm{C}$. The current paper is focused on the investigations of microstructural alternations and their impact on resulting hardness of commercially available PM-manufactured cold work tool steel Vanadis 6, which was subjected to the subzero treatment at a temperature of $-140^{\circ} \mathrm{C}$ for different

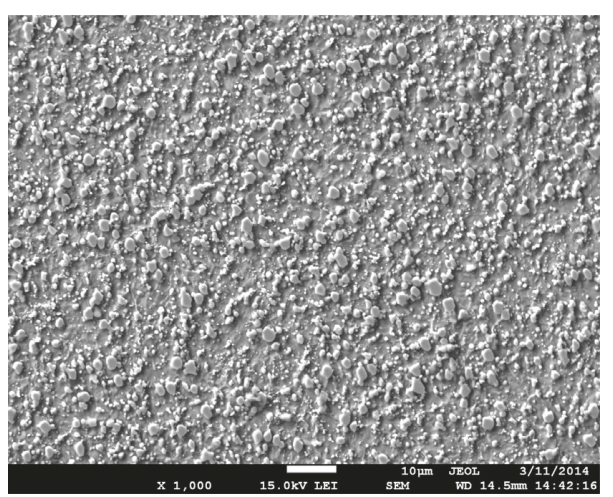

FIGURE 1: SEM micrograph showing the microstructure of the Vanadis 6 steel in as-delivered state.

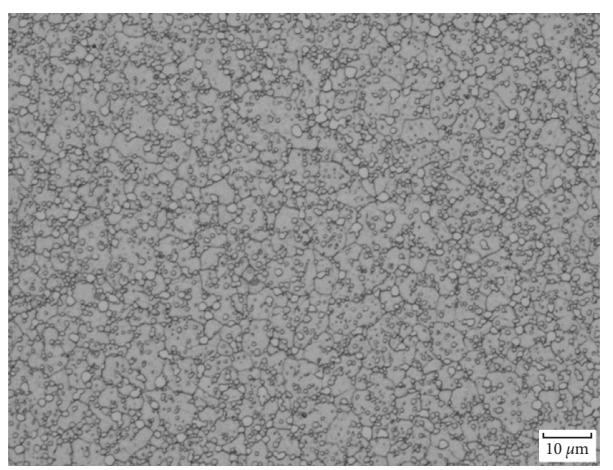

FIGURE 2: Light micrograph showing the microstructure of the Vanadis 6 steel after SZT at $-140^{\circ} \mathrm{C}$ for $17 \mathrm{~h}$.

durations. The same steel processed by room temperature quenching as well as the samples after subzero treatment at $-196^{\circ} \mathrm{C}$ has been used as the reference material.

\section{Experimental}

The experimental material was the tool steel Vanadis 6 with nominally $2.1 \% \mathrm{C}, 1.0 \% \mathrm{Si}, 0.4 \% \mathrm{Mn}, 6.8 \% \mathrm{Cr}, 1.5 \% \mathrm{Mo}$, and $5.4 \% \mathrm{~V}$ and $\mathrm{Fe}$ as balance, made by PM. The steel was delivered in soft-annealed state (i.e., with ferrite-carbide microstructure), Figure 1, and its hardness was $284 \mathrm{HV}$ 10. The carbides are distributed uniformly within the matrix, with no preferential orientation.

Samples for the microstructural investigations were cylinders with a diameter of $17 \mathrm{~mm}$ and height of $6 \mathrm{~mm}$. Conventional heat treatment (CHT) consisted of the following steps: heating up to the austenitizing temperature of $1050^{\circ} \mathrm{C}$ in a vacuum furnace, holding at the temperature for $30 \mathrm{~min}$, and nitrogen gas quenching ( 5 bar). SZT has been completed at a temperature of $-140^{\circ} \mathrm{C}$ and for $4,10,17,24$, 36 , and $48 \mathrm{~h}$. No tempering of the steel was carried out in order to highlight the microstructural changes due to the SZT itself.

Metallographic samples were prepared by standard preparation line and etched with the Villela-Bain reagent for the light microscopy or with picric acid for the SEM observation. 


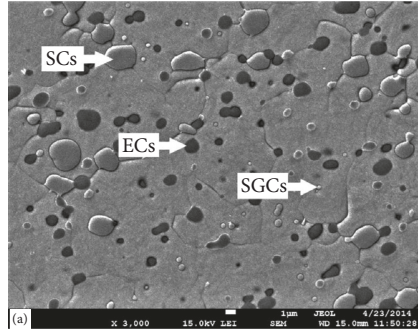

(a)

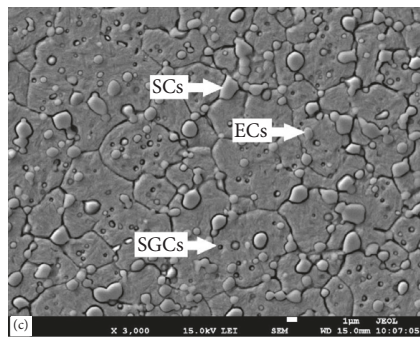

(c)

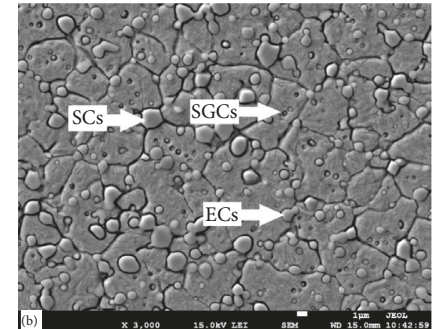

(b)

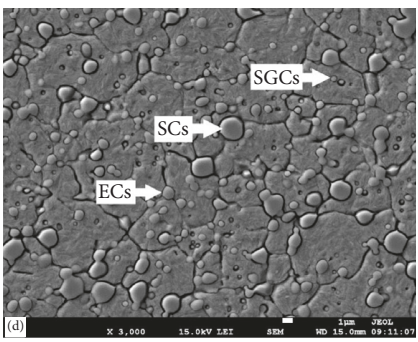

(d)

Figure 3: SEM micrographs showing the microstructure of Vanadis 6 steel (a) after CHT, (b) after SZT at $-140^{\circ} \mathrm{C}$ for $4 \mathrm{~h}$, (c) after SZT at $-140^{\circ} \mathrm{C}$ for $24 \mathrm{~h}$, and (d) after SZT at $-140^{\circ} \mathrm{C}$ for $48 \mathrm{~h}$.

The microstructure was recorded using the light microscope NEOPHOT 32 and the scanning electron microscope JEOL JSM $7600 \mathrm{~F}$ device equipped with an EDS detector (Oxford Instruments), at an acceleration voltage of $15 \mathrm{kV}$. For each duration of subzero treatment, quantitative analysis of carbides has been done on twenty randomly acquired SEM micrographs. For details of the categorization of the carbides, check $[1,28]$. X-ray diffraction patterns were recorded using a Phillips PW 1710 device with filtered $\mathrm{Co}_{\alpha 1,2}$ characteristic radiation, in the range $45-130^{\circ}$ of the two-theta angle. The amount of retained austenite $\gamma_{R}$ was determined according to the ASTM E975-13 standard [29]. The stress values in the retained austenite have been calculated from the lattice deformation (true strain), assuming pure elastic deformation (validity of Hook's law), and considering the Young modulus to be $225 \mathrm{GPa}$ [30].

Macrohardness measurements were completed by the Vickers (HV 10) method. Each metallographic specimen was measured 5 times, and the mean value and standard deviation from the measurements were calculated. The austenite grain size $G$ was determined by the Snyder-Graff method by the formula

$$
G=[6.635 \log (\mathrm{S}-\mathrm{G})]+2.66,
$$

where S-G is the dimensionless Snyder-Graff intercept count number.

\section{Results and Discussion}

Figure 2 shows light micrograph of the examined steel after conventional quenching followed by SZT for $17 \mathrm{~h}$. The microstructure consists of matrix and undissolved carbides, which are uniformly distributed throughout the material. The matrix contains the martensite and retained austenite. The original austenitic grains are well visible. They are very fine-the grain size was determined to be $10.26 \pm 0.14$ according to the Snyder-Graff method.

SEM micrographs, Figures 3(a)-3(d) show typical microstructures of the Vanadis 6 tool steel after CHT and after SZT at $-140^{\circ} \mathrm{C}$ for different durations. The microstructure is composed of the matrix and three types of carbides, namely, the eutectic carbides (ECs), secondary carbides (SCs), and small globular carbides (SGCs). The population density of both the ECs and SCs is invariant over the heat treatment parameter range used. This is because the ECs do not undergo the dissolution during austenitizing, and the level of dissolution of the SCs is constant at fixed austenitizing temperature. The population density of SGCs increased with holding time at the temperature of SZT. This is clearly evident by comparing the microstructures in Figures 3(a)-3(d).

Detail SEM micrograph acquired at high magnification, Figure 4, demonstrates that the matrix is composed of the martensite and small amount of the retained austenite. The formations of retained austenite are located in-between the martensitic domains.

The population density of SGCs as a function of the duration of SZT is shown in Figure 5. It is obvious that the population density of SGCs increased very rapidly up to $24 \mathrm{~h}$ of soaking time and then rather slightly decreased. The mean values of population density of SGCs were $48 \times 10^{3}$, $176 \times 10^{3}, 179 \times 10^{3}, 198 \times 10^{3}, 209 \times 10^{3}, 193 \times 10^{3}$, and $183 \times 10^{3} / \mathrm{mm}^{2}$ for CHT samples and SZT samples for 4, 10, 17, 24,36 , and $48 \mathrm{~h}$, respectively. Here, it should be noted that the values, with respect to the statistical uncertainty at a level of $95 \%$, considerably overlap for the samples treated for 4 and $10 \mathrm{~h}$. It is shown that the maximum population density of SGCs was achieved for $24 \mathrm{~h}$ storage time at $-140^{\circ} \mathrm{C}$. The reference material treated at $-196^{\circ} \mathrm{C}$ had the maximum population density of SGCs of $193 \times 10^{3} / \mathrm{mm}^{2}$ for $24 \mathrm{~h}[19]$. 


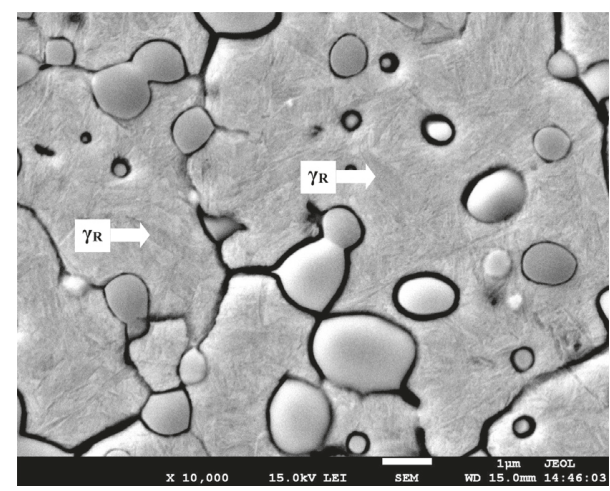

FIGURE 4: Detail SEM micrograph showing the microstructure of Vanadis 6 steel after SZT at $-140^{\circ} \mathrm{C}$ for $24 \mathrm{~h}$, with particular attention to the matrix microstructure.

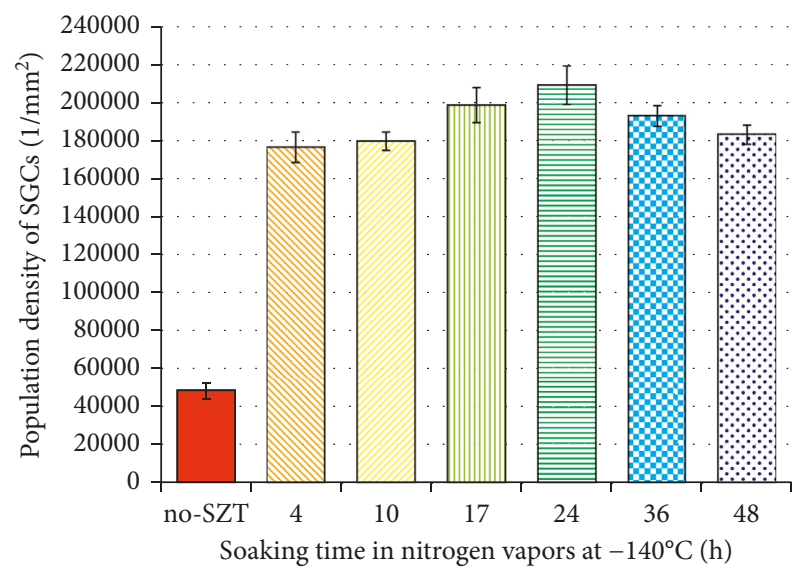

FIgUre 5: Population density of SGCs for samples processed by $\mathrm{CHT}$ and SZT, with various soaking times in nitrogen vapors at $-140^{\circ} \mathrm{C}$.

The obtained results are in excellent agreement with those presented by other investigators for different $\mathrm{Cr}$ ledeburitic steels $[2-4,7,18,22]$. Therefore, one can suggest that the fact that the SZT produces enhanced number and population density of these particles is generally a valid phenomenon for the ledeburitic cold work tool steels. In the recent two papers $[14,19]$, it has been demonstrated that the SZT at $-196^{\circ} \mathrm{C}$ increases the population density of SGCs in the Vanadis 6 steel. The values of population density were $169 \times 10^{3}, 188 \times 10^{3}, 193 \times 10^{3}$, and $160 \times 10^{3} / \mathrm{mm}^{2}$ for the material subzero treated for $10,17,24$, and $48 \mathrm{~h}$, respectively. By comparing the results obtained by two SZT temperatures, it is evident that the $\mathrm{SZT}$ at $-140^{\circ} \mathrm{C}$ produces rather higher population density of SGCs.

The $\gamma_{R}$ amount decreases considerably with the application SZT, Table 1. In no-SZT samples, the amount of $\gamma_{R}$ was 20.2 vol. \%, and for SZT samples with $48 \mathrm{~h}$ holding time, it was just 3.24 vol. \%.

The results of retained austenite amount measurements are consistent with those obtained by different researchers and for other $\mathrm{Cr}$ and $\mathrm{Cr}-\mathrm{V}$ ledeburitic steels $[3,4,7,9,22,31]$. These researchers have reported that, for instance, the AISI D2 steel is almost free of $\gamma_{R}$ after SZT
TABLE 1: Amount of retained austenite (vol. \%) in the SZT samples for various soaking times (h).

\begin{tabular}{lccccccc}
\hline SZT (h) & No-SZT & 4 & 10 & 17 & 24 & 36 & 48 \\
\hline$\gamma_{R}$ amount (vol. \%) & 20.2 & 3.94 & 4.64 & 4.25 & 4.16 & 3.6 & 3.24 \\
\hline
\end{tabular}

performed at $-196^{\circ} \mathrm{C}$ for $36 \mathrm{~h}$. Alternatively, Gavriljuk et al. [31] established that $\mathrm{Cr}-\mathrm{V}$ ledeburitic steel X220 CrMoV 13-4 contained around $4 \%$ of retained austenite after long-term SZT at $-196^{\circ} \mathrm{C}$. It is relevant to note that the $\gamma_{R}$ always exists in the microstructure of high-carbon highalloyed ledeburitic steels in their untempered state because the martensitic transformation is never completed in these materials.

In recent studies, it has been reported that the SZT in liquid nitrogen $\left(-196^{\circ} \mathrm{C}\right)$ carried out for $4,10,17,24$, and $48 \mathrm{~h}$ reduces the retained austenite amount to $9.9 \pm 1.6$, $2.9 \pm 0.6,2.1 \pm 0.5,2.9 \pm 0.6$, and $3.0 \pm 0.7$ vol. \%, respectively $[1,14,19]$. It is seen that the $\gamma_{R}$ amount is considerably lower for the specimens processed at $-140^{\circ} \mathrm{C}$ than that after processing at $-196^{\circ} \mathrm{C}$ for short time treatments but the treatments in liquid nitrogen remove the $\gamma_{R}$ more effectively after longer processing times. These results are counterintuitive on the first sight because one can expect rather stronger effect of lower processing temperature on the $\gamma_{R}$ amount after short treatment too. Also, at least twice higher $\gamma_{R}$ amounts in the specimens treated at $-140^{\circ} \mathrm{C}$ seem to be somewhat surprising since the processing temperature lies well below the characteristic martensite finish $\left(M_{f}\right)$ temperature $\left(-69^{\circ} \mathrm{C}\right)$. However, it should be noticed that there is much higher driving force for the martensitic transformation at $-196^{\circ} \mathrm{C}$, that is, the temperature difference between the processing temperature and $M_{f}$ is much higher for the treatment in liquid nitrogen than in nitrogen gas at $-140^{\circ} \mathrm{C}$. Lower $\gamma_{R}$ amount after short time treatment at $-140^{\circ} \mathrm{C}$, on the contrary, can be explained by the following consideration: Isothermal martensitic transformation, which proceeds during the hold at the lowest processing temperature, is connected with plastic deformation of freshly formed martensite, as demonstrated in [31-33]. It is logical to expect that plastic deformation proceeds faster at $-140^{\circ} \mathrm{C}$ than at $-196^{\circ} \mathrm{C}$, and this can act in favour of more pronounced $\gamma_{R}$ reduction in the early stage of isothermal martensitic transformation.

By comparing the data in Table 1 and the obtained results of population density of SGCs, Figure 5, it is obvious that there is close relation between these two microstructural parameters. Similar results were reported for the same material after subzero treatment in liquid nitrogen $[1,14]$. This indicates that there exists a general validity of the relation "the less the retained austenite is, the higher the population density of SGCs is." In other words, enhanced population density of SGCs can be attributed to more complete martensitic transformation.

Table 2 shows calculated hydrostatic stresses in the retained austenite for different SZT samples. It is shown that the compressive stresses in the retained austenite exceed $1000 \mathrm{MPa}$ and that the highest stresses were developed in the material that was SZT for $24 \mathrm{~h}$. These results are well 
TABle 2: Compressive stress $\sigma(\mathrm{MPa})$ in the specimen SZT for various durations.

\begin{tabular}{lcc}
\hline SZT $(\mathrm{h})$ & Lattice strain $\varepsilon(-)$ & Compressive stress $\sigma(\mathrm{MPa})$ \\
\hline 4 & 0.005539 & 1246 \\
10 & 0.006517 & 1466 \\
17 & 0.006746 & 1518 \\
24 & 0.007199 & 1620 \\
36 & 0.006786 & 1527 \\
48 & 0.006411 & 1442 \\
\hline
\end{tabular}

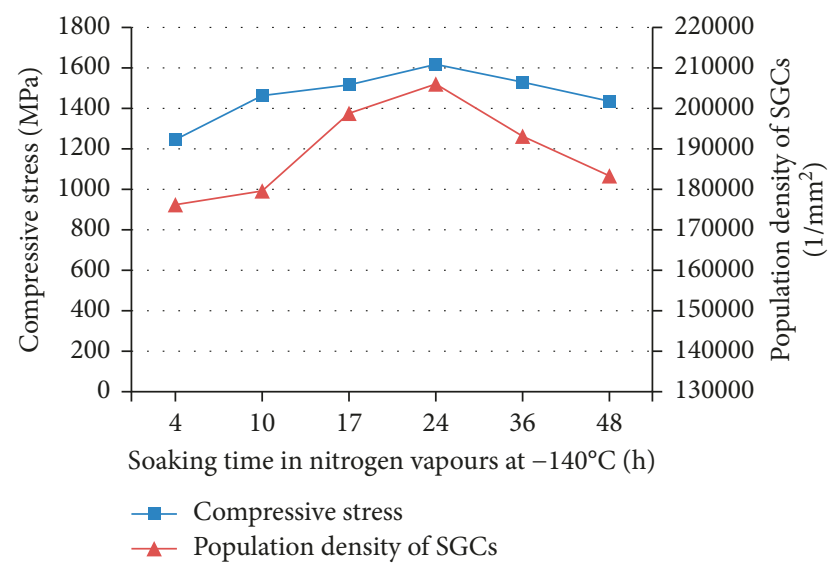

Figure 6: Dependence of the population density of SGCs and compressive stress in the retained austenite for specimens processed for various soaking times, at a temperature of $-140^{\circ} \mathrm{C}$.

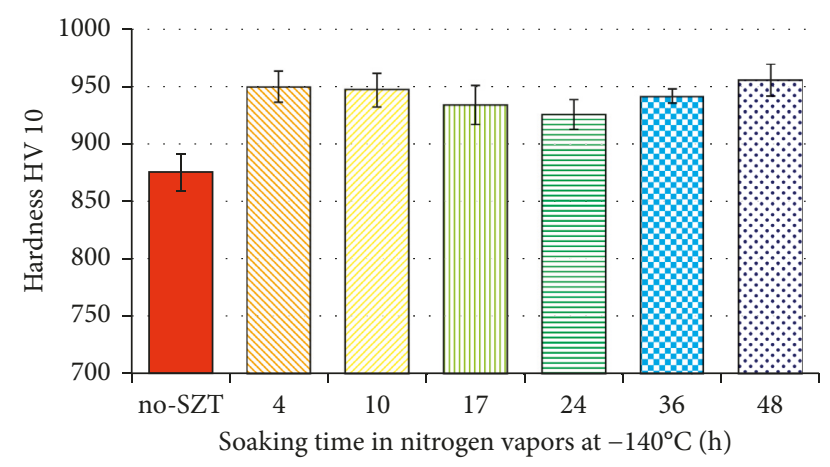

FIgURE 7: Bulk hardness HV 10 of the Vanadis 6 after SZT with different soaking times in nitrogen vapors.

consistent with the obtained results by Villa et al. [10] who reported on high compressive stresses in the retained austenite of 100Cr6 ball bearing steel after application of SZT. Figure 6 shows the dependence of both the population density of SGCs and compressive stress in austenite on the duration of SZT. For these two curves, the correlation coefficient was calculated to be 0.858961 . The correlation coefficient is greater than 0.8 ; hence, there is a strong dependency of these parameters.

At this place, it is noteworthy once again to pay attention to the presence of considerably enhanced population density of SGCs: As well known, the martensitic transformation is never completed in high-carbon steels. This is due to very low martensite finish $\left(M_{f}\right)$ temperature (it lies well below the room temperature in most cases) and also due to the positive volumetric effect of the transformation. As a result, compressive stresses are built up in the austenite, which hinder further progress in the transformation. In SZT, however, the temperature lies well below the $M_{f}$ and this makes a strong driving force for continuing of the transformation. As discussed and explained recently [14], the SGCs are a byproduct of the martensitic transformation that takes place at cryotemperatures and resulted from the effort of the material to relax the stresses and thereby enabling the further martensitic transformation. In the present study, close correlation between the compressive stress in the retained austenite and the population density of SGCs has been established. This is an additional supporting fact to the theory, which was elaborated and demonstrated recently [14].

The bulk hardness of SZT Vanadis 6 tool steel is shown in Figure 7. The hardness of CHT steel was $875 \pm 16 \mathrm{HV} 10$. The hardness of the SZT steel soaked in nitrogen vapor for 4, 10, $17,24,36$, and $48 \mathrm{~h}$ were $949 \pm 13.5,949.2 \pm 15.6,933.2 \pm 16.8$, $925.2 \pm 13.3,940.8 \pm 6.4$, and $954.6 \pm 14 \mathrm{HV} 10$, respectively. These results infer that the as-quenched bulk hardness of Vanadis 6 steel is improved due to SZT, whereas the improvement is almost independent on the duration of subzero treatment at $-140^{\circ} \mathrm{C}$. In other words, this kind of treatment increases the hardness compared to the state after CHT, but the effect of SZT can be considered as minimal for durations of this treatment longer than $4 \mathrm{~h}$.

The enhancement of as-SZT bulk hardness of SZT steel over the CHT one can be simply referred to the reduction of soft-retained austenite and to the increased population density of small globular carbides. The current results can be considered to be in an excellent agreement with those reported for subzero-treated AISI D2 [2, 3, 21, 34, 35] and AISI D3 steel $[4,18,36]$.

\section{Conclusions}

The Vanadis 6 ledeburitic tool steel has been austenitized, quenched, and subzero treated at a temperature of $-140^{\circ} \mathrm{C}$ for different durations. The obtained experimental results lead to following major conclusions:

(1) The Vanadis 6 tool steel is composed of the matrix (the martensite and the retained austenite), ECs, SCs, and SGCs (with a size up to $500 \mathrm{~nm}$, mostly around $100 \mathrm{~nm})$.

(2) The population density of small globular carbides is several times increased due to the SZT, with a maximum after SZT realized for a soaking time of $24 \mathrm{~h}$. The treatment at $-140^{\circ} \mathrm{C}$ leads to rather higher population density of these particles than the treatment at a temperature of boiling nitrogen.

(3) The application of SZT reduces the amount of retained austenite in Vanadis 6 tool steel considerably. Moreover, it has been found that the treatment at $-140^{\circ} \mathrm{C}$ acts more effectively in reduction of retained austenite in early stages of isothermal $\gamma$ to $\alpha^{\prime}$ 
transformation, while the treatment at a temperature of boiling nitrogen leads to approx. half-fold retained austenite amount after long time treatment.

(4) The as-quenched hardness of the Vanadis 6 tool steel manifests a moderate increase after SZT.

(5) There is a strong dependency of population density of SGCs and compressive stresses in the retained austenite. This fact supports the latest theory on the formation of enhanced population density of carbides, as a product of more complete martensitic transformation.

\section{Conflicts of Interest}

The authors declare that they have no conflicts of interest.

\section{Acknowledgments}

The authors acknowledge that this paper is a result of experiments realized within the project VEGA 1/0264/17. In addition, this publication is the result of the project implementation "Centre for Development and Application of Advanced Diagnostic Methods in Processing of Metallic and Non-Metallic Materials-APRODIMET," ITMS: 26220120014, supported by the Research \& Development Operational Programme funded by the ERDF.

\section{References}

[1] P. Jurči, M. Dománková, L. Čaplovič et al., "Microstructure and hardness of sub-zero treated and no tempered P/M Vanadis 6 ledeburitic tool steel," Vacuum, vol. 111, pp. 92101, 2015.

[2] D. Das, A. K. Dutta, and K. K. Ray, "Sub-zero treatments of AISI steel: part II wear behavior," Materials Science and Engineering: A, vol. 527, no. 9, pp. 2194-2206, 2010.

[3] D. Das and K. K. Ray, "Structure-property correlation of cubzero treated AISI D2 steel," Materials Science and Engineering: A, vol. 541, pp. 45-60, 2012.

[4] K. Amini, A. Akhbarizadeh, and S. Javadpour, "Investigating the effect of holding duration on the microstructure of 1.2080 tool steel during the deep cryogenic treatment," Vacuum, vol. 86, no. 10, pp. 1534-1540, 2012.

[5] A. I. Tyshchenko, W. Theisen, A. Oppenkowski et al., "Lowtemperature martensitic transformation and deep cryogenic treatment of a tool steel," Materials Science and Engineering: A, vol. 527, no. 26, pp. 7027-7039, 2010.

[6] P. Jurči, J. Sobotová, P. Salabová, O. Prikner, B. Šuštaršič, and D. Jenko, "Subzero treatment of P/M Vanadis 6 ledeburitic tool steel," International Heat Treatment and Surface Engineering, vol. 7, no. 3, pp. 125-128, 2013.

[7] A. Akhbarizadeh, S. Javadpour, K. Amini, and A. H. Yaghtin, "Investigating the effect of ball milling during the deep cryogenic heat treatment of the 1.2080 tool steel," Vacuum, vol. 90, pp. 70-74, 2013.

[8] D. N. Collins, "Deep cryogenic treatment of tool steels: a review," Heat Treatment of Metals, vol. 2, pp. 40-42, 1996.

[9] A. Akhbarizadeh, M. A. Golozar, A. Shafeie, and M. Kholghy, "Effects of austenitizing time on wear behaviour of D6 tool steel after deep cryogenic treatment," Journal of Iron and Steel Research, International, vol. 16, no. 6, pp. 29-32, 2009.
[10] M. Villa, K. Pantleon, and M. A. J. Somers, "Evolution of compressive strains in retained austenite during sub-zero Celsius martensite formation and tempering," Acta Materialia, vol. 65, pp. 383-392, 2014.

[11] P. F. Stratton, "Optimizing nano-carbide precipitation in tool steels," Materials Science and Engineering: A, vol. 449-451, pp. 809-812, 2007.

[12] M. J. Van Genderen, A. Boettger, R. J. Cernik, and E. J. Mittemeijer, "Early stages of decomposition in ironcarbon and iron-nitrogen martensites: diffraction analysis using synchrotron radiation," Metallurgical Transactions A, vol. 24, no. 9, pp. 1965-1973, 1993.

[13] M. Preciado and M. Pellizzari, "Influence of deep cryogenic treatment on the thermal decomposition of Fe-C martensite," Journal of Materials Science, vol. 49, no. 23, pp. 8183-8191, 2014.

[14] P. Jurči, "Sub-zero treatment of cold work tool steelsmetallurgical background and the effect on microstructure and properties," HTM Journal of Heat Treatment and Materials, vol. 72, no. 1, pp. 62-68, 2017.

[15] D. N. Collins and J. Dormer, "Deep cryogenic treatment of a D2 Cold-work tool steel," Heat Treatment of Metals, vol. 3, p. 71, 1997.

[16] K. Amini, A. Akhbarizadeh, and S. Javadpour, "Investigating the effect of the quench environment on the final microstructure and wear behaviour of 1.2080 tool steel after deep cryogenic heat treatment," Materials \& Design, vol. 45, pp. 316-322, 2013.

[17] A. Akhbarizadeh, K. Amini, and S. Javadpour, "Effect of simultaneous magnetic field and deep cryogenic heat treatment on the microstructure of 1.2080 tool steel," Materials \& Design, vol. 35, pp. 484-490, 2012.

[18] K. Amini, A. Akhbarizadeh, and S. Javadpour, "Effect of deep cryogenic treatment on the formation of nano-sized carbides and the wear behaviour of D2 tool steel," International Journal of Minerals, Metallurgy, and Materials, vol. 19, pp. 795-799, 2012.

[19] P. Jurči, M. Kusý, J. Ptačinová, V. Kuracina, and P. Priknerová, "Long-term sub-zero treatment of $\mathrm{P} / \mathrm{M}$ Vanadis 6 ledeburitic tool steel-a preliminary study," Manufacturing Technology, vol. 15, p. 41, 2015.

[20] H. Berns, "Restaustenit in ledeburitischen Chromstählen und seine Umwandlung durch Kaltumformen, Tiefkühlen und Anlassen," HTM Journal of Heat Treatment and Materials, vol. 29, p. 236, 1974, (in German).

[21] CH. Surberg, P. Stratton, and K. Lingenhoele, "The effect of some heat treatment parameters on the dimensional stability of AISI D2," Cryogenics, vol. 48, no. 1-2, pp. 42-47, 2008.

[22] D. Das, A. K. Dutta, and K. K. Ray, "Optimization of the duration of cryogenic processing to maximize wear resistance of ASIS D2 steel," Cryogenics, vol. 49, no. 5, pp. 176-184, 2009.

[23] D. Das, R. Sarkar, A. K. Dutta, and K. K. Ray, "Influence of sub-zero treatments on fracture toughness of AISI D2 steel," Materials Science and Engineering: A, vol. 528, no. 2, pp. 589-603, 2010.

[24] J. Sobotová, P. Jurči, and I. Dlouhý, "The effect of subzero treatment on microstructure, fracture toughness, and wear resistance of Vanadis 6 tool steel," Materials Science and Engineering: A, vol. 652, pp. 192-204, 2016.

[25] J. Ptačinová, V. Sedlická, M. Hudáková, I. Dlouhý, and P. Jurči, "Microstructure-Toughness relationships in sub-zero treated and tempered Vanadis 6 steel compared to conventional treatment," Materials Science and Engineering: A, vol. 702, pp. 241-258, 2017. 
[26] W. Reitz and J. Pendray, "Cryoprocessing of materials: a review of current status," Materials and Manufacturing Processes, vol. 16, no. 6, pp. 829-840, 2001.

[27] Z. Zurecki, "Cryogenic quenching of steel revisited," in Proceedings of the 23rd Heat Treating Society Conference, D. Herring and R. Hill, Eds., vol. 106, Pittsburgh, PA, USA, 2005.

[28] P. Bílek, J. Sobotová, and P. Jurči, "Evaluation of the microstructural changes in $\mathrm{Cr}-\mathrm{V}$ ledeburitic tool steel depending on the austenitization temperature," Materials and Technology, vol. 45, p. 489, 2011.

[29] ASTM E975-13, Standard Practice for X-Ray Determination of Retained Austenite in Steel with Near Random Crystallographic Orientation, vol. 3, ASTM Book of Standards, West Conshohocken, PA, USA, 2004.

[30] Vanadis 6 Super Clean, "High performance powder metallurgical cold work tool steel," http://www.uddeholm.com.

[31] V. G. Gavriljuk, W. Theisen, V. V. Sirosh et al., "Lowtemperature martensitic transformation in tool steels in relation to their deep cryogenic treatment," Acta Materialia, vol. 61, no. 5, pp. 1705-1715, 2013.

[32] J. Pietikainen, "Effects of the Aging of martensite on its deformation characteristic and on fracture in $\mathrm{Fe}-\mathrm{Ni}-\mathrm{Si}-\mathrm{C}$ steel," Journal of the Iron and Steel Institute, vol. 1, p. 74, 1968.

[33] P. Jurči, M. Dománková, M. Hudáková, J. Ptačinová, M. Pašák, and P. Palček, "Characterization of microstructure and tempering response of conventionally quenched, shortand long-time sub-zero treated PM Vanadis 6 ledeburitic tool steel," Materials Characterization, vol. 134, pp. 398-415, 2017.

[34] M. Pellizzari and A. Molinari, "Deep cryogenic treatment of cold work tool steel," in Proceedings of the 6th International Tooling Conference, J. Bergstrom, G. Fredriksson, M. Johansson, O. Kotik, and F. Thuvander, Eds., vol. 547, Karlstad University, Karlstad, Sweden, 2002.

[35] D. Das, K. K. Ray, and A. K. Dutta, "Influence of temperature of sub-zero treatments on the wear behaviour of die steel," Wear, vol. 267, no. 9-10, pp. 1361-1370, 2009.

[36] A. Akhbarizadeh and S. Javadpour, "Investigating the effect of as-quenched vacancies in the final microstructure of 1.2080 tool steel during the deep cryogenic heat treatment," Materials Letters, vol. 93, pp. 247-250, 2013. 


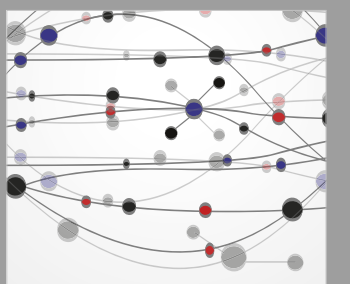

The Scientific World Journal
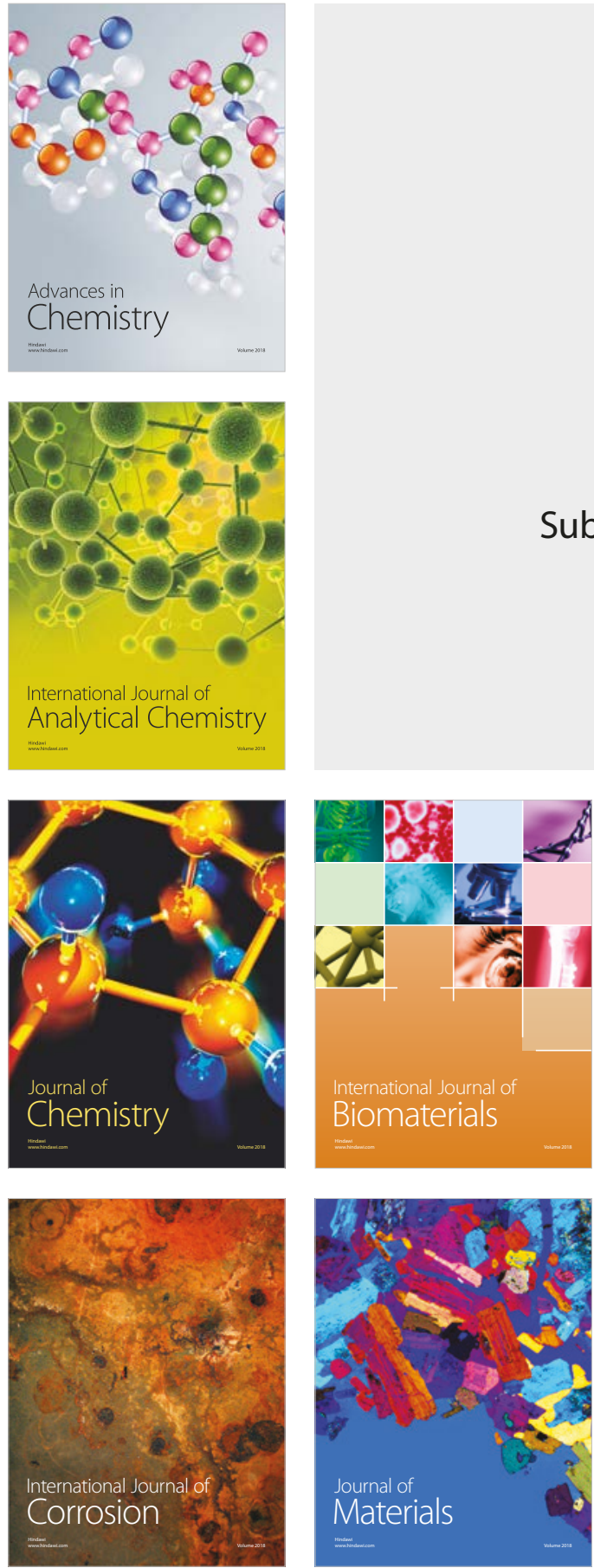

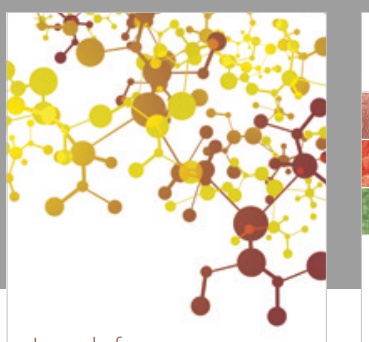

Journal of

Applied Chemistry
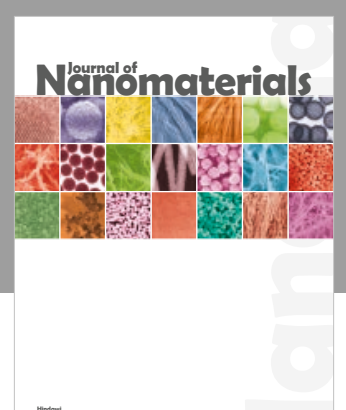

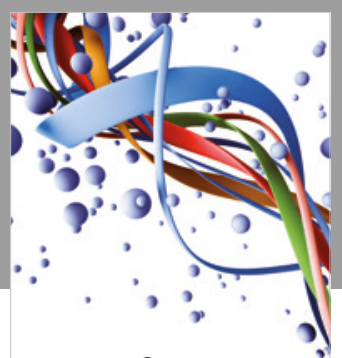

Scientifica

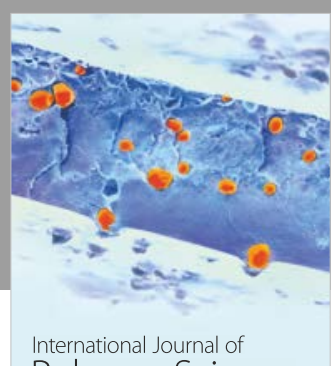

Polymer Science

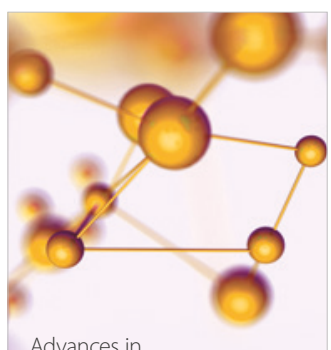

Physical Chemistry
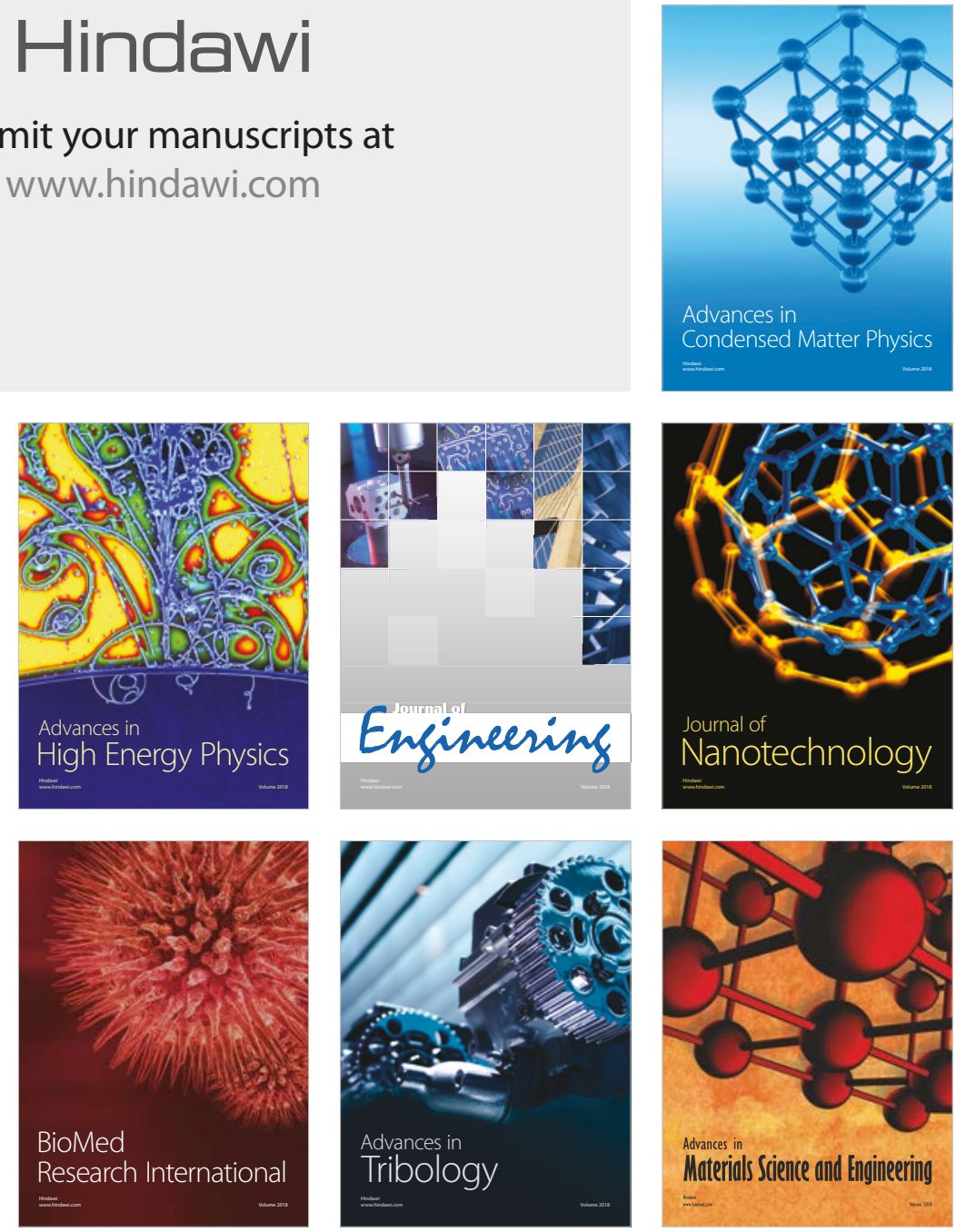